\title{
SYSTEMIC PSYCHOLOGICAL-PEDAGOGICAL APPROACH TO THE HUMANIZATION OF SCHOOL EDUCATION IN UKRAINE: A PRACTICAL ASPECT
}

УДК 159.923.5

DOI https://doi.org/10.32843/2663-

5208.2020.12-1.39

\section{Юрченко В.М.}

д.психол.н., професор кафедри психології

ПВНЗ «Міжнародний економікогуманітарний університет імені академіка Степана Дем'янчука» Грищук М.М.

к.психол.н., доцент кафедри психології ПВНЗ «Міжнародний економікогуманітарний університет імені академіка Степана Дем'янчука»

\section{Свердлова т.Г.}

к.пед.н., доцент каредри

японської фрілології

Київський національний

лінгвістичний університет
Статтю присвячено проблемі поліпшення психічного здоров'я школярів у контексті нагальної проблеми гуманізації фрункціонування вітчизняної посттоталітарноі системи освіти як одного з основних психотравмувальних чинників дитячої психіки. Мається на увазі спрямування їі, перш за все, на забезпечення психічного здоров'я учнів, тісно пов'язаного з тими психічними станами, які вони переважно переживають під час перебування в школі. Без збереження психічного здоров'я учнів неможливий їхній повноцінний особистісний розвиток, забезпечення якого, як відомо, виступає головною метою розпочатої освітньої реформи.

Нами проведено системне психолого-педагогічне дослідження проблеми гуманізаціі вітчизняної середньої освіти в контексті світового гуманістичного освітнього руху. У статті окреслено теоретико-методологічні засади дослідження прочесу гуманізації шкільної освіти, головне місце в яких займає системний підхід як новий загальнонауковий рівень пізнання. Підтверджено, що реалізований у проведеному дослідженні системний психолого-педагогічний підхід до процесу гуманізації вітчизняної шкільної освіти $є$ есрективним методологічним та практичним засобом вивчення складних психолого-педагогічних явищ: шкільного навчально-виховного процесу, психічного стану учня тощо. Представлено розроблену та апробовану авторську процедуру одержання кількісних показників психічного стану задоволеності учня усіма аспектами функціонування його школи та загального рівня їі гуманності, які можуть слугувати засобами практичної допомоги психологам та педагогам у процесі системного гуманістично орієнтованого ресормування конкретних навчальних закладів. Зроблено висновок, що українська освітня система знаходиться в процесі найвірнішого гуманістично орієнтованого реформування, бо на сучасному етапі розвитку людства 3 його глобалізаційними суперечностями саме гуманістична освіта покликана нейтралізувати їх шляхом виховання психічно здорової, гуманної, творчої, високоморальної особистості, здатної подолати не тільки міжетнічні та міжрелігійні консрлікти, а й глобальні екологічні та соціальні проблеми.

Ключові слова: психічне здоров'я, гуманізація освіти, системний підхід, психіч- ний стан, коефріцієнт рівня гуманності школи.

The article is devoted to the problem of improving the mental health of schoolchildren in the context of the urgent problem of humanizing the functioning of the national post-totalitarian system of education as one of the main psycho-traumatic factors of the children's psyche. This refers, first of all, to ensuring the mental health of the students, closely linked to the mental states that they mainly experience while in school. Without preserving the mental health of the students, it is impossible for them to complete their personal development, which, as we know, serves as the main purpose of the educational reform that has begun.

We have conducted a systematic psychologica and pedagogical study of the problem of humanization of national secondary education in the context of the world humanistic educational movement. The article outlines the theoreti$\mathrm{cal}$ and methodological principles of the study of the process of humanization of school education, the main place in which occupies the systematic approach as a new general scientific level of knowledge. It is confirmed that the systematic psychological and pedagogical approach to the process of humanization of the national school education implemented in the study is an effective methodological and practical means of studying complex psychological and pedagogical phenomena: school educational process, mental state of the student, etc. The author's developed and tested procedure has been presented for obtaining quantitative indicators of a student's mental state of satisfaction with all aspects of the functioning of their school and the general level of its humanity, which can serve as a practical help to psychologists and educators in the process of systematically humanistic oriented reform of specific educational institutions. It is concluded that the Ukrainian educational system is in the process of the most prominent humanist oriented reform, because at the present stage of human development, with its globalization contradictions, humanistic education is called to neutralize them by nurturing mentally healthy, humane, creative and highmoral personality, able to overcome not only international and inter-religious conflicts, but also global environmental and social issues. Key words: mental health, humanization of education, systematic approach, mental state, school humanity ratio.
Постановка проблеми. Результати досліджень вітчизняних учених красномовно свідчать, що сучасна економічна, екологічна та соціально-політична ситуація в Україні не сприяе збереженню психічного здоров'я її населення, особливо дитячого (В. Панок,
Л. Бурлачук, Н. Максимова, 3. Кісарчук, Т. Титаренко, О. Захаров, О. Лічко, Г. Абрамова та ін.). У цьому зв'язку дуже актуальною стає проблема гуманізації функціонування вітчизняної посттоталітарної системи освіти (Г. Балл, М. Бургін, М. Боришевський, С. Муса- 
тов, І. Зязюн, Т. Левченко та ін.) як одного 3 основних психотравмувальних чинників дитячої психіки, тобто спрямування ії, перш за все, на забезпечення психічного здоров'я учнів, тісно пов'язаного з тими психічними станами, які вони переважно переживають під час перебування у школі. Наявність зв'язку психічного здоров'я з переважаючими психічними станами суб'єкта випливає навіть із відомого визначення поняття «психічне здоров'я» як психічного стану душевного благополуччя, що характеризується відсутністю хворобливих психічних явищ і адекватною зовнішнім проявам регуляцією поведінки та діяльності [1].

Що ж до нашої сучасної школи як можливої соціально зумовленої причини негативних психічних станів школярів, то психологи сходяться на думці, що передусім психотравмувальною для дитини з моменту початку занять стає сама традиційна авторитарна система навчання, в якій вона не повноправний активний суб'єкт навчального процесу, а безправний пасивний його об'єкт. У такій ситуації у школяра виникає безліч проблем і труднощів, пов'язаних з адаптацією до шкільного режиму, з перевантаженням та перевтомою, із взаємовідносинами з учителями та однолітками, зі змінами в сімейній обстановці тощо, переживання яких спричиняе у нього негативний/ невротичний психічний стан [2; 3]. При цьому слід відзначити, що емоційні порушення у дітей, викликані тією чи іншою ситуацією, можуть мати тимчасовий характер (початкова невротизація), а можуть стати стійкими психічними розладами з подальшим невротичним розвитком особистості [4].

Українська система освіти знаходиться в процесі гуманістично орієнтованого реформування, і дуже важливо, щоб серед багатьох його важливих завдань не було загублено найважливіше - збереження психічного здоров'я учнів, без якого неможливий їній повноцінний особистісний розвиток. На наше переконання, забезпечити виконання цього завдання може тільки системний психолого-педагогічний підхід до розпочатої освітньої реформи. Це пояснюється тим, що у другій половині XX ст. в усіх галузях людського пізнання набули найбільш широкого розповсюдження саме системні дослідження, що засвідчило наявний процес зміни парадигми усього наукового мислення. На зміну стандартній раціональній концепції методології науки з їі прагненням до формально-логічних принципів прийшли альтернативні системні, у яких увагу зосереджено, перш за все, на науково-історичних даних. Така ситуація в науці призвела до визнання появи нового загальнонаукового методологічного рівня (системний підхід), який зайняв місце між універсальним філософським (найвищим) та конкретно науковим, здійснюючи продуктивний зв'язок між ними [5].
Постановка завдання. Мета статті обґрунтувати актуальність проблеми збереження психічного здоров'я школярів та методологічну ефективність системного психолого-педагогічного підходу до процесу гуманізації вітчизняної шкільної освіти; представити розроблену та апробовану авторську процедуру одержання кількісних показників рівня гуманності окремо взятої школи та психічного стану задоволеності учня усіма аспектами ії функціонування, які можуть слугувати засобами практичної допомоги психологам та педагогам у процесі системного гуманістично орієнтованого реформування конкретних навчальних закладів.

Виклад основного матеріалу дослідження. Проведене нами багаторічне системне дослідження (розпочалося ще 90-х роках XX ст., одразу після набуття Україною незалежності і можливості будувати демократичне суспільство) теоретико-методологічних та практичних аспектів проблеми гуманізації вітчизняної освіти в контексті світового гуманістичного освітнього руху включало аналіз широкого спектра визначень змісту поняття «гуманізація освіти» (Я. Коменський, К. Роджерс, Ш. Амонашвілі, В. Євдокимов, В. Луценко, С. Гончаренко та ін.), її процесуальних принципів та напрямів, інших системних характеристик. Найточніше сутність цього явища, як нам здається, передає наше системне його розуміння як цілеспрямованого, керованого, цілісного процесу наближення освіти до гуманістичної, тобто такої, що відповідає передусім класичним (Сократ, Квінтіліан, Я. Коменський, Г. Песталоцці, Г. Сковорода) та сучасним (В. Сухомлинський, К. Роджерс, Ш. Амонашвілі) критеріям гуманності позиції навчального закладу щодо учнів [6].

Як показав наш системний аналіз (структурний, функціональний, компонентний), чотирма головними принципами (одночасно й напрямами) гуманізації освіти як цілісного процесу можна вважати: 1) демократизацію структури управління функціонуванням навчальних закладів; 2) перетворення взаємодії вчителя й учнів у процесі навчання на засіб їхнього творчого психічного саморозвитку; 3) створення умов для формування в учнів та вчителів особистості гуманіста, демократа, творця; 4) контроль та оптимізацію психофізіологічного стану учнів під час занять та всього перебування в школі. Кінцевим результатом процесу гуманізації освіти повинна стати вітчизняна освітня гуманістична система з усіма їі навчальними закладами, що мають саме визначені нами специфічні системні характеристики [6; 7].

Зрозуміло, що реалізація кожного з чотирьох принципів/напрямів процесу гуманізації освіти сприятиме перебуванню учнів у школах саме в позитивних психічних станах, тобто 
зміцненню їхнього психічного здоров'я. Але четвертий напрям, як свідчить його назва, повинен нести всю повноту професійної відповідальності психологів та педагогів за контроль і оптимізацію показників психічного стану/здоров'я учнів і потребує відповідного психологічного інструментарію.

у сферу практичних інтересів вітчизняних психологів негативні психічні стани школярів попали тільки в середині 80-х років, коли на території колишнього СРСР із великим запізненням починають розвиватися дитяча практична психологія і психологічна служба системи освіти. Безумовно, цьому не могла не сприяти діяльність ВОО3, спрямована на всебічне вивчення проблеми психічного здоров'я дорослих і дітей. Так, у доповіді групи експертів цієї поважної організації «Психічне здоров`я та психосоціальний розвиток дітей» (1979р.) на матеріалі досліджень у різних країнах світу аналізуються такі причини порушення психічного здоров'я дітей, як несприятливі соціальні чинники, стреси, соматичні захворювання, фізичні вади та спричинені ними негативні прояви в їх емоційній сфері та поведінці.

Слід відзначити, що цей аналіз підтвердив те, про що писав значно раніше М.Д. Левітов (1964р.), а саме, що емоційніпорушенняудітей (негативні психічні стани), викликані тією чи іншою ситуацією, можуть мати тимчасовий характер, а можуть стати стійкими, тобто психічними розладами, і призвести до соціальної дезадаптації. Більше того, експерти зробили важливий висновок, що проблеми психічного здоров'я дітей порівняно з дорослими мають більш прямий зв язок із навколишнім середовищем, особливо із соціально-психологічною ситуацією в сім'ї та школі. Цим вони ще раз підтвердили важливість ролі індивідуального соціального оточення у формуванні дитячого організму та особистості, на що вказував ще видатний психолог Л.С. Виготський, навіть запропонувавши таке досить ємне та точне психологічне поняття, як «соціальна ситуація розвитку дитини», найважливішими складниками якої є саме сім'я і школа [8].

Але при цьому слід відзначити, що, виходячи з класичної концепції неврозів В.М. Мясищева [9], школа може виступати масовим психотравмувальним або психозахисним чинником не сама по собі, а залежно від ставлення до неї учнів, тобто від їхнього стійкого психічного стану задоволеності або незадоволеності умовами та змістом навчального процесу. Так, негативне ставлення кожного конкретного учня до конкретної шкільної ситуації, пов'язане частіше за все з блокуванням його потреби в любові та захищеності (шкільна афективна депривація, про яку писав і з якою успішно боровся у своїй школі В.О. Сухомлинський), може спричинити так звані шкільні неврози, які проявляються як дезадаптивною поведінкою (неумотивована агресивність, страх школи, відмова відповідати біля дошки тощо), так і різними психосоматичними захворюваннями (головні болі, бронхіальна астма тощо).

При цьому відзначається негативний вплив цього стану на процес формування всієї особистості дитини: втрата чи значне послаблення пізнавальних мотивів, небажані зміни в інтересах та самооцінці, некраща переоцінка цінностей тощо. Звідси, не можна не погодитися з висновками А.І. Захарова, що невроз, в основі якого лежить внутрішній конфлікт дитини з оточуючим світом, школою, є хворобою передусім ї̈̈ особистості і під час вивчення причин кожного конкретного випадку слід у першу чергу вивчати сферу ставлень конкретної особистості [10].

Виходячи із цього, саме емпіричне вивчення ставлень конкретних учнів до всіх сфер життя школи і використання одержаних кількісних даних (показників) у подальшому вдосконаленні навчально-виховного процесу та соціально-психологічної атмосфери в школі (їх гуманізації) може стати дієвим позитивним експрес-засобом моніторингу психічного стану/ здоров'я учнів та спрямування коригувальних психолого-педагогічних дій у належний напрям.

Розроблені та апробовані в процесі реалізації нашої системної концепції гуманізації навчання [12; 13; 6] методи кількісного оцінювання ставлення учнів до різних сфер життя конкретної школи та рівня гуманності її навчально-виховного процесу, процедура одержання яких подається нижче, можуть бути особливо актуальними і корисними зараз (у контексті розпочатої гуманістично орієнтованої вітчизняної освітньої реформи) для роботи практичних психологів школи, керівників шкільних педагогічних колективів та органів освіти, спрямованої на гуманну мету зміцнення психічного здоров`я школярів, майбутнього нашої країни.

\section{Методика визначення коефіцієнтів задоволеності учня школою}

Для одержання кількісних показників ставлення учнів до школи ми розробили власну методику визначення комплексного та часткових коефіцієнтів їхньої задоволеності шкільним навчально-виховним процесом експертно-аналітичним методом. Сутність метода полягає у визначенні експертним оцінюванням коефіцієнтів значущості отриманих, у даному разі в результаті анкетування, параметрів для зведення їх у комплексний показник. До складу методики входять розроблена спеціально для учнів середньої школи Анкета, яка складається з 18-ти запитань та загальних даних про учня, і алгоритм розрахунків часткових коефіцієнтів та комплексного задоволеності учня школою (табл. 1). 
Учня

класу,

Анкета

Шановний учень! Будь ласка, уважно прочитай кожне запитання і підкресли той варіант відповіді, який збігається з твоєю думкою. Наперед дуже вдячні тобі!

1. Скільки років навчаєшся в цій школі?

2. В яку зміну зараз навчаєшся?
a) 1 ,
б) 2 ,
в) 3

3. Скільки днів на тиждень має заняття твій клас? $\begin{array}{ll}\text { а) } 5, & \text { б) } 6\end{array}$

4. Чи подобається тобі програма (добір предметів) навчання?
а) так, б) не дуже,
в) $\mathrm{Hi}$

5. Навчання в школі, на твою думку:
а) дуже складне,
б) складне,

в) середньої складності, г) просте.

6. Навчання в школі, на твою думку:
а) різноманітне,
б) одноманітне,
в) дуже одноманітне.

7. Навчання в школі викликає у тебе:

а) дуже сильну втому, б) середню втому,

в) не викликає втоми.

8. Навчання в школі, на твою думку, потребує:

а) великої нервової напруги,

б) помірної нервової напруги,

в) ніякої нервової напруги.

9. Чи вважаєш ти навчання в школі цікавим?
а) так, б) не дуже,
в) ні

10. Чи задоволений(a) ти умовами навчання (класна кімната, парти, бібліотека, туалет, двір та. ін.)?
а) так, б) не дуже,
в) ні

11. Чи задоволений(а) ти харчуванням у школі?
а) так,
б) не дуже,
в) $\mathrm{Hi}$

12. Як ти оцінюєш стосунки між учнями свого класу?
а) дуже гарні, б) середні,
в) погані,
г) дуже погані

13. Як ти оцінюєш стосунки між учнями різних класів?
а) дуже гарні, б) середні,
в) погані,
г) дуже погані

14. Як ти оцінюєш свої стосунки з учителями?
a) гарні,
б) нормальні, в) поган

15. А тепер спробуй оцінити своє навчання взагалі. Чи подобається воно тобі?

а) дуже подобається, б) подобається,

в) байдуже, г) не подобається,

д) дуже не подобається

16. Чи маєш ти бажання змінити свою школу на іншу в найближчі рік-два?
a) $\mathrm{Hi}$,
б) не знаю,
в) так

17. Якщо ти маєш бажання змінити свою школу на іншу, то на яку? (підкресліть усі пункти, які Вам подобаються)

а) з однією зміною навчання,

б) із 5-денним робочим тижнем,

в) із вільним вибором предметів, що вивчаються, г) із більш складною програмою навчання,

д) із простішою програмою навчання,

е) із більш цікавою програмою навчання,

ж) із кращими умовами навчання,

з) із кращими стосунками між учнями,

и) із кращими стосунками між учнями та вчителями,

к) із професійною орієнтацією.

18. Уяви собі, що ти розпочинаєш своє шкільне навчання, чи вибрав(ла) би ти для цього твою теперішню школу?
a) так,
б) $\mathrm{Hi}$,
в) важко сказати

У табл. 1 для кожного запитання відповідної групи подається кількість балів на кожний варіант відповіді (а, б, в, г, д), його коефіцієнт значущості у групі та коефіцієнт значущості самої групи запитань, а також формула визначення коефіцієнта відповідного часткового ставлення до окремої сфери життя школи (задоволеності нею) (Кч.задов.). Після визначення чотирьох часткових коефіцієнтів задоволеності розраховується комплексний коефіцієнт задоволеності (Ккомпл.задов.) учня школою. Процедура розрахунків усіх п'яти коефіцієнтів представлена під табл. 1.

Для визначення коефіцієнтів значущості параметрів були опитані експерти-психологи та педагоги високої кваліфікації. Різний рівень кваліфікації експертів ураховувався коефіцієнтами поправки, які визначалися за допомогою нарахування балів експертам (за кожний рік стажу за фахом - 0,5 бали). Цим коефіцієнтом ураховувалася вага думки кожного експерта у формуванні колегіального рішення щодо коефіцієнта значущості параметрів.

Експертам було запропоновано оцінити в межах шкали 0-1 внесок кожного параметра та групи параметрів у формування комплексного показника. Із цих оцінок аналітичним методом з урахуванням ваги думки кожного експерта визначено коефіцієнти значущості параметрів та груп параметрів, які внесені у відповідні формули для розрахунків часткових і комплексного коефіцієнтів задоволеності учня школою (табл. 1).

Процедура обробки заповненої кожним конкретним учнем Анкети за допомогою табл. 1 виглядає так. Кожна відповідь учня на запитання Анкети 4-9, спрямована на з'ясування його ставлення до навчального навантаження (складність, різноманітність, напруженість, цікавість тощо), одержує відповідний бал згідно з табл. 1, який підставляється у формулу для одержання часткового коефіцієнта задоволеності учня навчальним навантаженням (Кч задов. № 1). Далі кожна відповідь на запитання Анкети 10, 11, спрямована на 3'ясування ставлення учня до умов навчання (класна кімната, парти, бібліотека, харчування 
тощо), одержує відповідний бал і підставляється у формулу для одержання часткового коефіцієнта задоволеності учня умовами навчання (Кч задов. № 2).

Таблиця 1

Алгоритм визначення часткових та комплексного коефіцієнтів задоволеності учня школою за Анкетою

\begin{tabular}{|c|c|c|c|c|c|c|c|c|c|}
\hline \multirow{2}{*}{  } & \multirow{2}{*}{  } & \multicolumn{7}{|c|}{$\begin{array}{c}\text { Кількість балів по варіан- } \\
\text { тах відповідей (а, б, в, г). } \\
\text { Значення параметрів } \\
\text { Б1,....Б18 залежно від } \\
\text { відповіді на запитання } \\
\text { (a, б, в, г). }\end{array}$} & \multirow{2}{*}{ 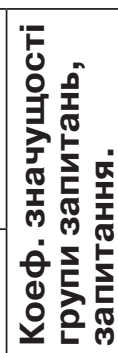 } \\
\hline & & 0 & $\begin{array}{l}\text { N } \\
\text { O. } \\
0\end{array}$ & $\begin{array}{l}\mathscr{m} \\
\text { m } \\
0\end{array}$ & $\begin{array}{l}n \\
0 \\
0\end{array}$ & $\begin{array}{l}\mathscr{0} \\
\mathscr{0} \\
0^{-}\end{array}$ & $\begin{array}{l}\stackrel{R}{R} \\
0^{-}\end{array}$ & - & \\
\hline & № 1 . & \multicolumn{7}{|c|}{ Ставлення до навчання } & 0,35 \\
\hline 1. & 54 & B & & & б & & & $\mathrm{a}$ & 0,1 \\
\hline 2. & Б5 & $\mathrm{a}$ & & б & & B & & $\Gamma$ & 0,1 \\
\hline 3. & Б6 & B & & & б & & & $\mathrm{a}$ & 0,1 \\
\hline 4. & 57 & a & & & 0 & & & B & 0,3 \\
\hline 5. & 58 & $\mathrm{a}$ & & & б & & & $\mathrm{B}$ & 0,3 \\
\hline 6. & Б9 & B & & & б & & & $\mathrm{a}$ & 0,1 \\
\hline \multicolumn{10}{|c|}{$\begin{array}{l}\text { Кч задов. №1 навантаженням =0,1*Б4+ } \\
+0,1^{\star} Б 5+0,1^{\star} Б 6+0,3^{\star} Б 7+0,3^{*} \text { Б8+0,1 } 1^{\star} \text { Б } 9\end{array}$} \\
\hline & 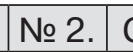 & \multicolumn{7}{|c|}{ Ставлення до умов навчання } & 0,1 \\
\hline 1. & Б10 & $B$ & & & б & & & $\mathrm{a}$ & 0,6 \\
\hline 2. & Б11 & B & & & б & & & $\mathrm{a}$ & 0,4 \\
\hline \multicolumn{10}{|c|}{$\begin{array}{c}\text { Кч задов. №2 умовами навчання }= \\
=0,6^{*} Б 10+0,4^{\star} \text { Б } 11\end{array}$} \\
\hline & \begin{tabular}{|l|l|} 
№ 3. & C \\
\end{tabular} & \multicolumn{7}{|c|}{$\begin{array}{c}\text { Ставлення до соціально-пси- } \\
\text { хологічної атмосфери }\end{array}$} & 0,25 \\
\hline 12. & 512 & $r$ & & $\mathrm{~B}$ & & б & & $\mathrm{a}$ & 0,45 \\
\hline 13. & Б13 & $\Gamma$ & & B & & б & & a & 0,1 \\
\hline 14. & 514 & B & & & & & & $\mathrm{a}$ & 0,45 \\
\hline \multicolumn{10}{|c|}{$\begin{array}{c}\text { Кч задов. №3 психологічним кліматом = } \\
=0,45^{\star} Б 12+0,1^{\star} Б 13+0,45^{\star} Б 14\end{array}$} \\
\hline & № 4 . & \multicolumn{7}{|c|}{ Ставлення до навчання } & 0,3 \\
\hline 15. & 515 & д & 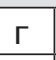 & & $\mathrm{B}$ & & б & $\mathrm{a}$ & 0,3 \\
\hline 16. & 516 & B & & & б & & & $\mathrm{a}$ & 0,2 \\
\hline 17. & Б17 & \multicolumn{7}{|c|}{$\begin{array}{c}\text { за відповіді ТАК від } \\
1 \text { віднімаємо 0,1 за } \\
\text { кожну помітку при } \\
\text { підзапитаннях (а.....к) }\end{array}$} & 0,2 \\
\hline 18. & Б18 & б & & & B & & & $a$ & 0,3 \\
\hline \multicolumn{10}{|c|}{ 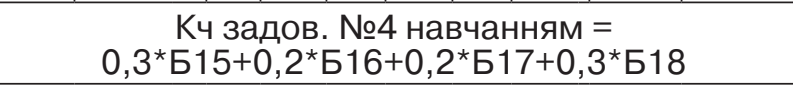 } \\
\hline \multicolumn{10}{|c|}{  } \\
\hline
\end{tabular}

Аналогічно визначаються бали за кожну відповідь на запитання Анкети 12-14 (ставлення до міжособистісних стосунків) та на запитання 15-18 (ставлення до навчального процесу) і підставляються відповідно у формули для одержання часткових коефіцієнтів задоволеності учня шкільним соціально-психологічним кліматом (№ 3) та навчальним процесом (№ 4). У табл. 1 подано формулу одержання комплексного коефіцієнта задоволеності учня школою: з часткових коефіцієнтів та по всіх запитаннях Анкети. Кількісний діапазон усіх коефіцієнтів від 0 до 1 (дуже низький рівень - 0-0,24; низький - 0,25-0,49; середній - 0,5-0,74; високий $-0,75-1,0)$.

За необхідності ця методика може бути використана для одержання, безумовно, корисних даних про рівень задоволеності школою батьків учнів, для чого треба в Анкеті тільки змінити звернення до учня на звернення до батьків.

\section{Методика визначення коефіцієнта задоволеності учня спілкуванням з учителем}

У розробленій нами методиці, яка є модифікацією тесту «Вчитель - учень» [11, с. 256], використовується анкета з 24 запитань, що виявляють ставлення учня до вчителя за трьома параметрами (по вісім питань): гностичному (рівень компетентності вчителя), емоційному (рівень симпатії учня до вчителя), поведінковому (реальна взаємодія вчителя з учнем).

Тест «Вчитель - учень» передбачає, що кожне запитання, відповідь на яке збігається з ключем тесту, оцінюється в один бал. Для гностичного компонента це запитання 1, 4, 7, 10, 19, 22 («так») та запитання 13, 16 («ні»), для емоційного компонента - 8, 11, 14, 23 («так»), 2, 5, 17, 20 («ні»), для поведінкового компонента - 3, 6, 12, 18 («так») та запитання 9, 15, 21, 24 («ні»).

У нашій модифікації методики ми зберегли цей алгоритм розрахунку показників за кожним із трьох компонентів, але доповнили його алгоритмом одержання комплексного коефіцієнта задоволеності (Кзадов.) учня спілкуванням $з$ учителем, розробленим експертно-аналітичним методом для молодших школярів, підлітків та старшокласників (табл. 2).

у табл. 2 подано одержані експертним методом коефіцієнти значущості кожного з трьох компонентів тесту для кожної вікової групи і формули для розрахунку відповідних комплексних показників задоволеності учня спілкуванням з учителем. Це значно розширює практичні можливості методики, бо вихідний iї варіант не рекомендувався для молодших школярів. Кількісний діапазон коефіцієнтів задоволеності учня спілкуванням з учителем від 0 до 1 (дуже низький рівень - 0-0,24; низький - 0,25-0,49; середній - 0,5-0,74; високий $-0,75-1,0$. 
Таблиця 2

Алгоритм визначення коефіцієнта задоволеності учня спілкуванням з учителями

\begin{tabular}{|c|c|c|c|c|c|}
\hline \multirow{2}{*}{ 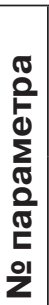 } & \multirow{2}{*}{ 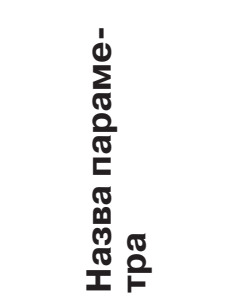 } & \multirow{2}{*}{ 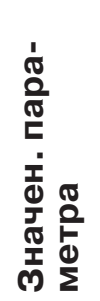 } & \multicolumn{3}{|c|}{$\begin{array}{c}\text { Коеф. значущост } \\
\text { пар-ра для різ- } \\
\text { них вікових груп } \\
\text { (класів) } \\
\end{array}$} \\
\hline & & & 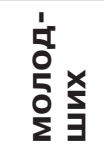 & 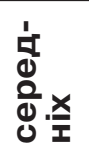 & $\begin{array}{l}\frac{2}{\pi} \\
\frac{5}{5}\end{array}$ \\
\hline 1 & $\begin{array}{l}\text { Гностичний } \\
\text { параметр }\end{array}$ & Бг & 0,1 & 0,2 & 0,4 \\
\hline 2 & $\begin{array}{l}\text { Емоційний } \\
\text { параметр }\end{array}$ & Бе & 0,4 & 0,4 & 0,2 \\
\hline 3 & $\begin{array}{l}\text { Поведінковий } \\
\text { параметр }\end{array}$ & Бп & 0,5 & 0,4 & 0,4 \\
\hline
\end{tabular}

Тоді, враховуючи коефіцієнт нормування 8 по 8-ми запитаннях анкети для визначення кожного параметра:

Кзадов.вчителями (мол.кл) $=$ $=0,1^{\star}$ Бг $/ 8+0,4^{\star}$ Бе $/ 8+0,5^{\star}$ Бп $/ 8$

Кзадов.вчителями (сер.кл) $=$ $=0,2^{\star}$ Бг $/ 8+0,4^{\star}$ Бе $/ 8+0,4^{\star}$ Бп $/ 8$ Кзадов.вчителями (старш.кл) $=$ $=0,4^{\star} Б г / 8+0,2^{\star}$ Бе $/ 8+0,4^{\star} Б$ Бп $/ 8$

\section{Методика визначення коефіцієнта гуманності школи}

Наша практика досліджень психічних станів школярів із метою пошуків шляхів зміцнення їхнього психічного здоров'я показала корисність використання такої запропонованої нами умовної комплексної характеристики школи, як «гуманність навчально-виховного процесу школи». Розроблена нами методика визначення коефіцієнта гуманності школи передбачає зведення в один комплексний показник усіх представлених вище середніх кількісних показників (задоволеності школою з боку учнів та батьків, середніх психологічних показників таких професійно важливих якостей усіх вчителів школи, як емпатія, високий рівень за тестом І. Юсупова та агресивність, низький рівень - за тестом А. Ассингера і показника соціально-психологічного клімату в педагогічному колективі школи [11, с. 319]) експертно-аналітичним методом (табл. 3).

\section{Алгоритм визначення коефіцієнта} гуманності школи

\begin{tabular}{|c|c|c|}
\hline $\begin{array}{c}\text { № } \\
\text { nара- } \\
\text { метра }\end{array}$ & $\begin{array}{c}\text { Назва параметра } \\
\text { 3 його К }\end{array}$ & $\begin{array}{c}\text { Коеф. } \\
\text { значущості } \\
\text { параметра }\end{array}$ \\
\hline $\mathbf{1}$ & $\mathbf{2}$ & $\mathbf{3}$ \\
\hline 1 & К агресивності вчителів & 0,05 \\
\hline 2 & К емпатії вчителів & 0,15 \\
\hline
\end{tabular}

Таблиця 3 (закінчення)

\begin{tabular}{|c|c|c|}
\hline $\mathbf{1}$ & $\mathbf{2}$ & $\mathbf{3}$ \\
\hline 3 & $\begin{array}{c}\text { К соц.-псих. клімату } \\
\text { упед. кол-ві }\end{array}$ & 0,2 \\
\hline 4 & К задов. учнів учителями & 0,3 \\
\hline 5 & К задов. учнів школою & 0,2 \\
\hline 6 & К задов. батьків школою & 0,1 \\
\hline
\end{tabular}

Тоді:

Кгуманності школи $=-0,05$ * Кагр. + $+0,2$ * Кемп. + 0,05 * Кпс. кл +

$+0,5$ * Кзадов. учнів учителями. +

$+0,1$ * Кзадов. учнів школою +

$+0,1{ }^{*}$ Кзадов. батьків школою,

де: Кагр $=\frac{A}{60}$, де А - показник рівня агресивності вчителів;

60 - нормуючий коефіцієнт до шкали 0-1;

Кемn $=\frac{E}{90}$, де Е - показник рівня емпатійності вчителів;

90 - нормуючий коефіцієнт до шкали 0-1;

Кис.кл. $=\frac{M+39}{78}$, де М - показник псих. клімату;

39; 78 - нормуючі коефіцієнти до шкали 0-1.

У табл. 3 представлено коефіцієнти значущості кожного із шести параметрів у комплексному показнику, одержані експертним шляхом, та формулу для визначення самого комплексного показника гуманності навчально-виховного процесу школи. Кількісний діапазон показника - від 0 до 1 (дуже низький рівень - 0-0,24; низький рівень - 0,25-0,49; середній рівень - 0,5-0,74; високий рівень 0,75-1,0).

Розроблені методики й одержувані з їх допомогою показники пройшли апробацію у трьох школах міста Рівного (умовно школи №№ $1,2,3)$. Результати дослідження представлено в табл. 4.

Таблиця 4

Комплексні показники рівня гуманності досліджених шкіл

\begin{tabular}{|c|c|c|c|c|c|c|c|}
\hline \multirow[b]{2}{*}{ 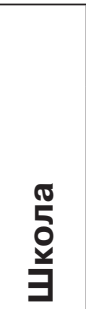 } & \multicolumn{6}{|c|}{$\begin{array}{c}\text { Часткові показники гуманності } \\
\text { школи } \\
\end{array}$} & \\
\hline & 은 & $\sum_{0}^{\dot{2}}$ & 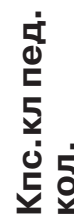 & 章 & $\begin{array}{l}\text { 弟 } \\
\text { o } \\
0 \\
\text { o }\end{array}$ & 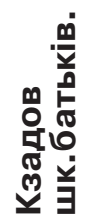 & \\
\hline ปo 1 & & & & & & & \\
\hline 02 & & & & & & & \\
\hline 03 & & & & 67 &, 74 &,$/ 2$ & \\
\hline
\end{tabular}

Аналіз даних табл. 4 показує, що комплексні показники рівня гуманності всіх трьох 
шкіл, в яких інтегрується, доповнюється і дещо об єктивується в проекції на шкільну соціальну-психологічну атмосферу одержана в попередніх показниках інформація про ставлення учнів та їхніх батьків до школи, знаходяться в середньому кількісному діапазоні, але все ж на різних позиціях. Школа № 3 - на межі з високим рівнем, школа № 2 - ближче до низького, а школа № 1 - на стійкому середньому рівні. Цей факт свідчить про те, що педколектив саме школи № 3, в якому зафіксовано найвищий коефіцієнт психологічного клімату $(0,9)$, найбільшою мірою здійснює психозахисну функцію щодо психічного здоров'я учнів.

Таким чином, розроблені й апробовані нами кількісні методи вивчення ставлення (психічний стан задоволеності) учнів та їхніх батьків до різних аспектів шкільного життя, гуманності навчально-виховного процесу допомагають не тільки констатувати наявний кількісний рівень відповідних показників, що саме по собі дуже корисно, а й визначати напрями спрямування зусиль керівників освіти, педагогічних колективів та шкільних психологів щодо поліпшення існуючої ситуації в школі і зміцнення психічного здоров`я учнів.

Висновки з проведеного дослідження. Українська освітня система знаходиться у процесі найвірнішого гуманістично орієнтованого реформування, бо на сучасному етапі розвитку людства з його глобалізаційними суперечностями саме гуманістична освіта покликана нейтралізувати їх шляхом виховання психічно здорової, гуманної, творчої, високоморальної особистості, здатної подолати не тільки міжетнічні та міжрелігійні конфлікти, а й глобальні екологічні та соціальні проблеми. Дуже важливо, щоб серед багатьох важливих завдань вітчизняної освітньої реформи не було загублено найважливіше - збереження психічного здоров'я учнів, без якого неможливий їхній повноцінний особистісний розвиток.

Проблеми психічного здоров'я дітей порівняно з дорослими мають більш прямий зв'язок із навколишнім середовищем, особливо із соціально-психологічною ситуацією у сім'ї та школі, з тими психічними станами, в яких переважно вони там перебувають. Школа може виступати масовим психотравмувальним або психозахисним чинником не сама по собі, а залежно від ставлення до неї учнів, тобто від їхнього стійкого психічного стану задоволеності або незадоволеності умовами та змістом навчального процесу.

Реалізований у проведеному нами дослідженні системний психолого-педагогічного підхід до процесу гуманізації вітчизняної шкільної освіти зарекомендував себе як ефективний методологічний та практичний засіб вивчення складних психолого-педагогічних явищ: психічного стану учня, навчально-виховного процесу школи тощо.

Розроблені й апробовані нами кількісні показники рівня гуманності окремо взятої школи та психічного стану задоволеності учня усіма аспектами ії функціонування можуть слугувати ефективними засобами практичної допомоги психологам та педагогам у процесі системного гуманістично орієнтованого реформування конкретних навчальних закладів за умови дотримання представленої в статті авторської процедури розрахунків.

Перспективу подальшої науково-дослідницької роботи вбачаємо в продовженні розробленні ефективних засобів практичної допомоги психологам та педагогам у процесі системного гуманістично орієнтованого реформування конкретних навчальних закладів системи освіти України.

\section{ЛITЕРАТУРА:}

1. Петровский А.В., Ярошевский М.Г. Психология : словарь. Москва, 1990.

2. Бурминская Г.В., Карабанов О.А., Лидерс А.Т. Возрастное психолого-педагогическое консультирование. Москва, 1990.

3. Прихожан А.М. Проблема подросткового кризисна. Психологическая наука и образование. 1997. № 1.

4. Грищук М. Психопрофрілактика та психокорекція початкової невротизації дітей шкільного віку : авторефр. дис. ... канд. психол. наук ; Інститут психології ім. Г.С. Костюка НАПН України. Київ, 2010. 22 с.

5. Юрченко В.М. Психічні стани людини: системний опис : монографрія. Рівне : Перспектива, 2006. 574 с.

6. Юрченко В.М. Віленська-Свердлова Т.Г. Крос-культурна еволюція гуманістичних ідей в освіті: психолого-педагогічний аналіз. Культурологічні та психолого-педагогічні аспекти гуманізації освіти : науково-методичний збірник / за ред. Г.О. Балла. Київ : Наукова думка, 1998. С. 130-192.

7. Свердлова Т.Г. Теоретичні засади процесу гуманізації освіти в Японії : автореф. дис. ... канд. педагог. наук ; Національний педагогічний університет ім. М.П. Драгоманова. Київ, 2006. 19 с.

8. Выготский Л.С. Педагогическая психология. Москва, 1991.

9. Мясищев В.Н. Личность и неврозы. Ленинград, 1960.

10. Захаров А.И. Неврозы у детей и подростков. Ленинград, 1988.

11. Рогов Е.И. Настольная книга практического психолога в образовании. Москва, 1996.

12. Юрченко В.М. Психологічні засади гуманізації середньої освіти: найважливіші підходи. Психологічні аспекти гуманізації освіти. Книга для вчителя / за ред. Г.О. Балла. Київ ; Рівне, 1996. С. 23-34.

13. Юрченко В.М. Психофрізіологічна складова системного підходу до гуманізації навчання в школі. Психологія - школі : збірник матеріалів II міжрегіонального науково-практичного семінару, м. Рівне, 16-18 січня 1997 р. Київ : Наукова думка, 1997. С. 13-23. 